Int. Arch. Allergy 1967;31:I-VIII

\title{
Contents, Vol. 31, 1967
}

\section{International Archives}

of

Allergy and Applied Immunology

Incorporating the Transactions of the Collegium Internationale Allergologicui and the

Proceedings of the International Association of Asthmology and of

National Allergy Societies

E. L. BECKER, Washington, D.C. H. BLOCH, Basel C. J. C. BRITTON, London W. E. BROCKLEHURST,

Edinburgh T. BROMAN, Göteborg L. BUSINCO, Roma A. CERLETTI, Basel A. L. DE

WECK, Bern J. DUCHAINE, Bruxelles G. ESTRADA DE LA RIVA,

Havana P. G. H. GELL, Birmingham J. GLAZER, Tel Aviv R. A. GOOD, Minneapolis, Minn.

W. GRONEMEYER,

Bad Lippsprínge

CONTRIBUTING EDITORS:

A. GRUMBACH, Zurich

B. HALPERN, Paris

T. INDERBITZIN, Boston, Mass.

H. ISLIKER, Lausanne

E. A. KABAT, New York

R. KELLER, Zurich

J. LECOMTE, Liège

J. R. MARRACK, Cambridge

J. A. MORETTI, Montevideo

T. OGATA, Tokyo

A. OLIVEIRA-LIMA,

Rio de Janeiro D. ORDMAN, Johannesburg Ö. OUCHTERLONY, Göteborg W. PAGEL,

London R. PANZANI, Marseille

C. RIMINGTON, London

M. ROCHA E SILVA, São Paulo

I. M. ROITT, London

B. ROSE, Montreal

G. RUIZ MORENO, Buenos Aires

J. RUNNSTRÖM, Stockholm

B. SCHICK, New York

E. SORKIN, Davos-Platz

A. STOLL, Basel

H. STORCK, Zurich

A. TISELIUS, Uppsala

Z. TRNKA, Geneva 
B. H. WAKSMAN, New Haven,

Conn.

G. L. WALDBOTT, Detroit, Mich. R. G. WHITE, London

EDITORS-IN-CHIEF:

tombs H. C. Goodman

F.Hahn

D. Harley P. Kalló $\beta$

dge Geneva

Freiburg/Br.

London Helsingborg

W. Kaufman

F. Milgrom

G. B. West

Bridgeport, Conn.

Buffalo, N.Y.

Carshalton, Surrey

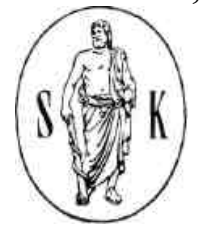

1967

Vol. 31

BASEL (Schweiz) S. KARGER NEW YORK

All rights, including that of translation into foreign languages, reserved.

Photomechanic reproduction (photocopy, microcopy) of this book or part of it without special permission of the publishers is prohibited

(C)

Copyright 1967 by S. Karger AG., Basel

Printed in Switzerland by Buchdruckerei Aargauer Tagblatt AC, Aarau

Olichés: Aberegg-Steiner \& Cie, Bern

Contents

Aas, K. (Oslo): Studies of Hypersensitivity to Fish. Studies of Different Fractions of Extracts from

Cod Muscle Tissue 239

Aho, K. (Helsinki): Studies of $\gamma \mathrm{G}$ Red Cell Heteroantibodies in Normal and in Mononucleosis Serum 304

Airo, R.: vide Astaldi, G.

Arala-Chaves, M. P. (Louvain); Lebago_, E. G. (Jolimont) and Heremans, J. F. (Louvain):

Fractionation of Human Leukocyte Extracts Transferring Delayed Hyper

sensitivity to Tuberculin 353

Astaldi, G.; Airò, R. and Lisino, T. (Tortona); Rodriguez-Paradisi, E. and Novelli, E.

(Buenos-Aires): Depressed Blastic Development of Human Lymphocytes in PHA-Cell-

Cultures after Intravenous Injection of PHA 568

Auerbach-Pascal, T.: vide Manski, W. Bacal, H. L.: vide Eisen, A. H. Barbaro, J.: vide Zvaifler, N. J. 
Barrett, J. T.; Nilsson, B. and Ghiron, C. A (Columbia, Mo.):

A Serologic Investigation of the System: Trypsinogen-Trypsin

399

Berning, E.: vide Kerp, L. Berrens, L.: vide Bleumink, E. Bhattacharya, S. K.: vide Prasad, D. N.

Bleumink, E.; Berrens, L. and Young, E. (Utrecht):

Studies on the Atopic Allergen in Ripe Tomato Fruits. II. Further Chemi

cal Characterization of the Purified Allergen 25

Börjeson, J.; Chess $\gamma$ n, L. N. and Landy, M. (Bethesda, Md.):

Dissociation of Leukagglutinating and Transforming Properties of Phyto-hemagglutinin by the

Coating of Lymphocytes with Vi Polysaccharide . 184

Buckley, Rebecca H.: vide Metzgar, R. S. Buechner, H.: vide Salvaggio, J.

Caron, G. A. (Portland):

The Effect of Antigens in Combination on Lymphocyte Transformation

in vitro521

Caron, G. A. (Portland, Ore.):

The Effects of Concentration on Antigen Induced Lymphocyte Trans

formation in vitro 441

Carvalho, I. F. de: vide Oliveira, H. L.

Chessin, L. N.: vide Börjeson, J.

Collins-Williams, C; Tkachyk, S.J. ; Toft, B. and Moscarello, M. (Toronto):

Quantitative Immunoglobulin Levels (IgG, IgA and IgM) in Children . 94

Coombs, R. R. A.: vide Dingle, J. T.

Crowle, A. J. and $\mathrm{Hu}, \mathrm{C} \mathrm{C}$ (Denver, Col.):

Delayed Hypersensitivity in Mice to Dextran

Cruchaud, S. and Frei, P. C. (Lausanne):

Demonstration of Specific Antibodies on Human Circulating Lympho

cytes by a New Technique 455

Das, P. K.: vide Prasad, D. N.

Diengdoh, J. V. and Turk, J. L. (London):

Cytochemical Studies on the Effect of Antigen on Peritoneal Exudate

Cells from Guinea Pigs with Delayed Hypersensitivity 261

Dingle, J. T.; Fell, Honor B. and Coombs, R. R. A. (Cambridge):

The Breakdown of Embryonic Cartilage and Bone Cultivated in the Pres

ence of Complement-Sufficient Antiserum. 2. Biochemical Changes and

the Role of the Lysosomal System 282

Eisen, A. H. and Bacal, H. L. (Montreal):

Immunologic Response to Bacterial Vaccine 14

Fell, Honor, B.: vide Dingle, J. T. Flad, H. D.: vide Jansz, A.

Ford, H. and Kirsner, J. B. (Chicago, 111.):

Iso-Antibodies to Colon 449

Frei, P. C.: vide Cruchaud, S. Gambhir, S. S.: vide Prasad, D. N.

Gery, I. and Waksman, B. H. (New Haven, Conn.):

Studies of the Mechanism whereby Adjuvant Disease is Suppressed in Rats

Pretreated with Mycobacteria

Ghiron, C. A.: vide Barrett, J. T.

Gold, D.; Lengy, J.; Lass, N. and Tager, A. (Tel-Aviv): 
Studies on Culex pipiens molestus in Israel. 2. Skin Response in Man to

Extracts from the Mosquito 274

Coppers, Velta and Paulus, J. J. (Minneapolis):

Allergenic Compounds in Nature 546

Guirgis, H. M. (Dundee):

Separation of a Histamine-Binding Fraction from Normal Human Serum 587

Guttman, P. H. (San Francisco, Calif.):

Effect of Thymectomy and Splenectomy on the Course of X-Ray Induced Progressive

Intercapillary Glomerulosclerosis in the Mouse Kidney ... 163

H $\lambda$ lbert, S. P.: vide Manski, W.

Hanson, L. Å. (Göteborg) and Johansson, B. G. (Lund):

Studies on the Elimination of the Complement Inhibiting Activity of Human y-Globulin Using

Degradation with Plasmin or Gel Filtration . 380

Heremans, J. F.: vide Arala-Chaves, M. P. Herzog, P.: vide Streijcek, J.

Jansz, A.; Flad, H.-D.; Koffler, D. and Miescher, P. A. (New York City, N.Y.):

The Effect of Vitamin A on Experimental Immune Thyroiditis .... 69

Javier, P.: vide Manski, W. Johansson, B. G.: vide Hanson, L. Å.

Jones, Valerie E. and Ogilvie, Bridget M. (London):

Reaginic Antibodies and Immunity to Nippostrongylus brasiliensis in the Rat.

III. Passive Immunity in the Young Rat 490

Kano, K. and Milgrom, F. (Buffalo, N.Y.):

Nature of Isoantibodies Combining with Human Cell Cultures 209

Keller, H. U. and Sorkin, E. (Davos):

Studies on Chemotaxis. V. On the Chemotactic Effect of Bacteria . . . 505

Keller, H. U. and Sorkin, E. (Davos-Platz):

Studies on Chemotaxis. VI. Specific Chemotaxis in Rabbit Polymorpho-

nuclear Leucocytes and Mononuclear Cells 575

Kerp, L.; Sihler, K.; Raju, S.; Berning, E. and Steinhilber, S. (Freiburg i.Br.):

Influence of Prednisolone and ACTH on the Formation of Insulin-Binding

Antibodies 195

Kirsner, J. B.: vide Ford, H. Koffler, D.: vide Jansz, A.

Korngold, L. (New York, N.Y.):

The Detection of Monoclonal Macroglobulinemia with Antisera Specific

for yM-Globulins 105

Kuroume, T.: vide Matsumura, T.

Landy, M.: vide Börjeson, J.

Lass, N.: vide Gold, D.

Lassus, A.: vide Mustakallio, K. K.

Laus-Filho, J. A.: vide Oliveira, H. L.

Lebacq, E. G.: vide Arala-Chaves, M. P.

Lengy, J.: vide Gold, D.

Levine, B. and Redmond, A. (New York):

Immunochemical Mechanisms of Penicillin Induced Coombs Positivity

and Hemolytic Anemia in Man

594

Liauw, H.-L.: vide Salvin, S. B.

Linna, T. J. (Uppsala): 
Transport of Tritium-Labelled DNA from the Thymus to Other Lymphoid Organs in Rabbits under Normal Conditions and after Administration of Endotoxin $\quad 313$

Lisino, T.: vide Astaldi, G.

Mccloskey, R. V. and Zmijewski, Ch. M. (Durham, N.C.):

Autohemagglutination by Blister Fluid 427

Manski, W.; Halbert, S. P.; Auerbach-Pascal, T. and Javier, P. (New York, N.Y.):

On the Use of Antigenic Relationships Among Species for the Study of

Molecular Evolution. I. The Lens Proteins of the Agnatha and Chondrich-

thyes 38

Manski, W.; Halbert, S. P. and Javier, P. (New York, N.Y.):

On the Use of Antigenic Relationships among Species for the Study of

Molecular Evolution. II. The Lens Proteins of the Choanichthyes and

Early Actinopterygii 475

Manski, W.; Halbert, S. P.; Javier, P. and Auerbach-Pascal, T. (New York, N.Y.):

On the Use of Antigenic Relationships Among Species for the Study of Molecular Evolution. III.

The Lens Proteins of the Late Actinopterygii . 529

Matsumura, T.; Kuroume, T. and Suzuki, M. (Maebashi, Gunma):

BDB Haemagglutination Applied to Food Allergy in Children 217

Menzel, A. E. O. and Sherman, W. B. (New York, N.Y.):

The Antibody Mechanism of Ragweed Allergy. Electrophoretic and

Chemical Studies. IV. Two Reaginic Variants Demonstrated by Rivanol

Fractionation, the Major Variant without Relationship to Beta-2A Glob

ulin 338

Metzgar, R. S. and Buckley, Rebecca H. (Durham, N. C.):

The Development of Homologous Skin-Sensitizing Antibodies in Experi

mental Thyroiditis 174

Miescher, P. A.: vide Jansz, A.

Milgrom, F.: vide Kano, K.

Moscarello, M.: vide Collins-Williams, C.

Mustakallio, K. K.; Lassus, A. and Wagner, O. (Helsinki):

Auto-Immune Phenomena in Syphilitic Infection: Rheumatoid Factor

and Cryoglobulins in Different Stages of Syphilis 417

Nilsson, B.: vide Barrett, J. T.

Novelli, E.: vide Astaldi, G.

Ogilvie, Bridget, M.: vide Jones, Valerie E.

Oliveira, H.-L. de; Laus-Filho, J. A.; Sarti, W. and Carvalho, I. F. de (São Paulo):

Prevention of Acute Immunologic Lung Change in Rats by an Isolated

Urine Fraction 551

Paulus, H. J.: vide Goppers, Velta Polak, L.: vide Turk, J. L.

Prasad, D. N.; Gambhir, S. S.; Singh, Gurmohan; Bhattacharya, S. K. and Das, P. K. (Varanasi):

Histamine Skin Sensitivity and Blood Histamine in Patients with Urticaria 230

Raju, S. vide Kerp, L. Redmond, A.: vide Levine, B. Rodriguez-Paradisi, E.: vide Astaldi, G.

Salvaggio, J.; Buechner, H.; Seabury, J. and Waguespack, H. (New Orleans, La.):

Bagassosis. II. Skin Reactivity to Crude Bagasse Extracts and Atopic Sta

tus of Patients 
Salvin, S. B. and Liauw, H.-L. (Summit, N. J.):

Hypersensitivity to Peptíde Fragments

366

Sarti, W.: vide Oliveira, H. L. Seabury, J.: vide Salvaggio, J. Sherman, W. B.: vide Menzel, A. E. O.

Sherwin, A. L. and Laviolette, R. (Montreal):

An Immunological Comparison of Central and Peripheral Tissues ... 152

Sicuters, F.; Franchi, G. and Bianco, P. L. del (Florence):

An Antaminic Drug, BC 105, in the Prophylaxis of Migraine. Pharmacolo

gical, Clinical, and Therapeutic Experiences 78

Sihler, K.: vide Kerp, L.

Singh, Gurmohan : vide Prasad, D. N.

Singhal, S. K.; Naspitz, C. K. and Richter, M. (Montreal):

The Action of Phytohemmagglutinin in Rabbits. I. The Enhancement of

the Primary Immune Response to Human Serum Albumin, Bovine

Gamma Globulin and Sheep Erythrocytes 390

Siç¿ueira, Maria; Passos, H. C. and Bier, O. G. (São Paulo):

Inhibitory Effect of Large Doses of Histamine on the Passive Arthus

Reaction 117

Sorkin, E.: vide Keller, H. U.

Spiegelberg, H. L. and Weigle, W. O. (La Jolla):

The Immune Response in Guinea Pigs Injected with Heterologous and

Altered Homologous Thyroglobulin 559

Steinhilber, S.: vide Kerp, L.

Strejgek, J.; Herzog, P. and Bielický, T. (Prague):

Allotypy of Serum Immunoglobulins in Systemic and Chronic Lupus erythe-

matosus 145

Suzuki, M.: vide Matsumura, T. Tager, A.: vide Gold, D. Tkachyk, S. J.: vide Collins-Williams, C. Toft, B.: vide Collins-Williams, C.

Turk, J. L. and Polak, L. (London):

Studies on the Origin and Reactive Ability in vivo of Peritoneal Exudate

Cells in Delayed Hypersensitivity 403

Turk, J. L.: vide Diengdoh, J. V. Wager, O.: vide Mustakallio, K. K. Waguespack, H.: vide

Salvaggio, J. Waksman, B. H.: vide Gery, I. Weigle, W. O.: vide Spiegelberg, H. L. Young, E.: vide Bleumink, E. Zmijewski, Ch. M.: vide Mccloskey, R. V.

Zvaifler, N. J. and Barbaro, J. (Washington, D.C.):

The Demonstration of Anaphylactic Antibody in the Primary Response of

Rabbits $\quad 465$

Proceedings: Round Table Conference on Tavegyl (HS 592) 607

Book Reviews 104,206,518,613

News Items $104,208,312,520$

Summaries $\quad 11,23,36,54,67,76,92,103,115,122,141,150,160,171,182,193,202,215$, $228,237,258,272,281,302,310,333,350,364,377,388,397,402,415,424,439,447,453$, $463,472,488,503,516,527,544,550,558,566,573,584,592,604$ 